Scientia Marina 85(4)

December 2021, 245-255, Barcelona (Spain)

ISSN-L: 0214-8358

https://doi.org/10.3989/scimar.05129.021

\title{
Occurrence and abundance of young mullet Mugil liza (Teleostei: Mugilidae) in the surf zone along the southern coast of Brazil
}

\author{
Valéria Marques Lemos ${ }^{1,4}$, Henrique $\mathrm{Cabral}^{2}$, Stephanie Pasquaud ${ }^{3}$, João Paes Vieira ${ }^{4}$ \\ ${ }^{1}$ Instituto de Oceanografia, Universidade Federal do Rio Grande, Av. Itália, km 8, Rio Grande CEP 96203-900, RS, Brazil. \\ (VML) (Corresponding author) E-mail: vavadeleom@yahoo.com.br. ORCID iD: https://orcid.org/0000-0003-1813-4982 \\ ${ }^{2}$ INRAE, Centre Nouvelle-Aquitaine - Bordeaux, UR EABX, 50, avenue de Verdun, Cestas, France. \\ (HC) E-mail: henrique.cabral@inrae.fr_ORCID iD: https://orcid.org/0000-0002-7646-6208 \\ ${ }^{3}$ MARE, Marine and Environmental Sciences Centre, Faculdade de Ciências da Universidade de Lisboa, Lisboa, Portugal. \\ (SP) E-mail: spasquaud@ @c.ul.pt. ORCID iD: https://orcid.org/0000-0002-2416-5841 \\ ${ }^{4}$ Brazilian Long-Term Ecological Research Programme (PELD), Rio Grande, Brazil. \\ (JPV) E-mail: vieira@ mikrus.com.br. ORCID iD: https://orcid.org/0000-0002-0669-9444
}

\begin{abstract}
Summary: The southern population of Mugil liza is distributed from Argentina $\left(47^{\circ} \mathrm{S}\right)$ to the state of São Paulo, Brazil $\left(23^{\circ} \mathrm{S}\right)$. Young mullets use the estuaries as nursery grounds, and prior to recruitment into estuaries they use the surf zone as a temporary habitat. Based on 12 consecutive months of sampling, this study used generalized linear models (GLM) to analyse the relationships between environmental variables and the presence and relative abundance of young mullets in the surf zone adjacent to six major estuaries in southern Brazil (between $29^{\circ} \mathrm{S}$ and $33^{\circ} \mathrm{S}$ ). Young mullets were present in all seasons over the sampling period, but the probability of occurrence was higher in winter and was associated with low temperatures. The water temperature alone explained more than half of the total deviance of the GLM models for presence $(23 \%)$ and abundance $(21 \%)$ of young mullets in the surf zone. Site 2 (Rio Grande) had lower temperatures in the colder months, the highest probability of occurrence of all collection sites and the greatest abundance ( $\mathrm{n}=3402$ ) of young M. liza, which represented $52 \%$ of the total of individuals $(\mathrm{n}=6493)$ caught among the six sites sampled.
\end{abstract}

Keywords: mullet; nursery areas; southern Brazil; surf zone; estuary; recruitment.

Presencia y abundancia de lisas Mugil liza (Teleostei: Mugilidae) jóvenes en la zona de oleaje en la costa sur de Brasil

Resumen: La población Sur de Mugil liza se distribuye desde Argentina $\left(47^{\circ} \mathrm{S}\right)$ hasta el estado de São Paulo, Brasil ( $\left.23^{\circ} \mathrm{S}\right)$ Las lisas jóvenes utilizan la zona de oleaje como hábitat temporal antes del reclutamiento en los estuarios. Basado en 12 meses de muestreo, este estudio utilizó modelos lineales generalizados (GLM) para analizar las relaciones entre las variables ambientales, la presencia y abundancia de lisas en la zona de oleaje adyacente a seis estuarios en el sur de Brasil (entre $29^{\circ} \mathrm{S}$ y $33^{\circ} \mathrm{S}$ ). La temperatura del agua por sí sola explicó más de la mitad de la desviación total de los modelos GLM para la presencia (23\%) y abundancia (21\%) de lisas en la zona de oleaje. Las lisas jóvenes estuvieron presentes en todas las estaciones, pero la probabilidad de ocurrencia fue mayor en invierno y se asoció con bajas temperaturas. Río Grande tuvo la mayor probabilidad de ocurrencia y la mayor abundancia $(n=3402)$ de $M$. liza jóvenes, representando el 52\% del total de individuos $(\mathrm{n}=6493)$ capturados entre las seis localidades muestreadas.

Palabras clave: lisas; zonas de cría; Sur del Brasil; zona de oleaje; estuarios; reclutamiento.

Citation/Como citar este artículo: Lemos V.M., Cabral H., Pasquaud S., Vieira J.P. 2021. Occurrence and abundance of young mullet Mugil liza (Teleostei: Mugilidae) in the surf zone along the southern coast of Brazil. Sci. Mar. 85(4): 245255. https://doi.org/10.3989/scimar.05129.021

Editor: A. Garcia-Rubies.

Received: September 13, 2020. Accepted: September 2, 2021. Published: November 23, 2021.

Copyright: ( $) 2021$ CSIC. This is an open-access article distributed under the terms of the Creative Commons Attribution 4.0 International (CC BY 4.0) License. 


\section{INTRODUCTION}

Estuaries and coastal lagoons are considered highly productive areas and are important refuge and nursery zones for several fish species with high economic and/or environmental value (Boehlert and Mundy 1988). Migratory marine species spawn in offshore waters, regularly enter estuaries in substantial numbers, particularly as juveniles, and use the nearshore marine waters as an alternative habitat (Boehlert and Mundy 1988). In southern Brazil, juveniles of many commercially and recreationally important fish species (Micropogonias furnieri [Desmarest, 1823], Brevoortia pectinata [Jenyns, 1842], Pogonias courbina [Linnaeus, 1766] and Mugil liza Valenciennes, 1836) use the estuarine areas as nurseries (Seeliger et al. 1998, Mai et al. 2019).

The Lebranche mullet, Mugil liza (Teleostei, Mugilidae), occurs from the Gulf of Mexico to the coast of Argentina. Using the mitochondrial control region, Heras et al. (2016) described two highly divergent M. liza populations: a northern population, which is distributed from Cuba to the state of Rio de Janeiro, Brazil, and a southern population, which is distributed from Rio Grande do Sul, Brazil, to Argentina. Mai et al. (2014) and Lemos et al. (2017) showed that the southern population encompasses the Rio Grande do Sul state and actually ranges from the state of São Paulo in southeastern Brazil $\left(23^{\circ} \mathrm{S}\right)$ to Argentina.

Mugil liza is commercially exploited in Argentina by a small-scale fishery that operates mainly in Samborombón Bay. Commercial catches were between 5.4 and $78.8 \mathrm{t}$ from 2000 to 2010 , with a maximum capture of $194.0 \mathrm{t}$ in 2004 (Castellini et al. 2017). In the southern states of Brazil (Rio Grande do Sul, Santa Catarina and Paraná) and São Paulo, the M. liza southern population fishery is a very important resource (Lemos et al. 2014, 2016, de Abreu-Mota et al. 2018), with a maximum reported capture of $13600 \mathrm{t}$ in 2007 (de Abreu-Mota et al. 2018). The Patos Lagoon estuary, located in the state of Rio Grande do Sul, is considered the main M. liza nursery area in Brazil (Herbst and Hanazaki 2014, de Abreu-Mota et al. 2018).

The southern population of M. liza performs an annual reproductive migration from Argentina, Uruguay and estuaries of southern Brazil, especially the Patos Lagoon estuary, to offshore spawning areas located on the Brazilian coast between northern Santa Catarina and Paraná $\left(28^{\circ}-26^{\circ} \mathrm{S}\right)$ (Lemos et al. 2014, 2016). Mugil liza is a single spawner and spawning occurs between May and July at temperatures of $19^{\circ} \mathrm{C}$ to $21^{\circ} \mathrm{C}$ in offshore waters (Lemos et al. 2014). According to the life cycle model proposed by Vieira (1991), M. liza larvae and early juveniles are neustonic and are carried, mainly by wind-driven currents, from offshore waters to the coast, where they concentrate in surf zones prior to recruitment to estuarine environments. This use of the coastal zone and migratory behaviour characterize M. liza as a marine estuarine-dependent species (Mai et al. 2019).

Martin and Drewry (1978) recognized a pre-juvenile stage for mullets starting at $11 \mathrm{~mm}$ total length (TL), and the transformation from the larval to the pre-juvenile stage ends at approximately $13 \mathrm{~mm}$ TL and involves a change from predaceous to iliophagous (detritivorous) feeding habits (Martin and Drewry 1978, Vieira 1991). Young mullets, which first appear in small schools along the coasts and in the estuaries, measure 18 to $28 \mathrm{~mm}$ in length (Vieira 1991, González-Castro and Minos 2016). In the coastal area of the state of Rio Grande do Sul, young mullets are frequently present and abundant in the surf zone throughout the year (Ramos and Vieira 2001, Rodrigues et al. 2015), which is also the case on the coast of Argentina (Acha 1990, Castellini et al. 2017). However, in the northern area of the southern population (state of São Paulo) (Mai et al. 2014), the presence of young mullets in the surf zone occurs shortly after the reproductive period, and individuals are less abundant or absent in the surf zone during the remaining months of the year (Favero and Dias 2015). It seems that there is a clinal decrease in surf zone occurrence from the northern to the southern limits of the southern population.

Surf zones of sandy beaches are important recruitment and nursery zones and migratory paths to other nearshore habitats (Strydom 2003, McLachlan and Brown 2006). Larvae and juvenile of estuary-dependent marine fishes move from offshore spawning grounds (initially passively but later by active migration) to surf zones (Boehlert and Mundy 1988). Despite the available information on recruitment of young fishes into estuaries worldwide, there is a paucity of information describing the factors driving the recruitment process (Strydom 2003). The aim of the present study was to compare the abundance of young M. liza $(\leq 30 \mathrm{~mm} \mathrm{TL})$ in the adjacent surf zones of six estuaries between $28.5^{\circ} \mathrm{S}$ and $33.7^{\circ} \mathrm{S}$ in southern Brazil and to determine which environmental variables are related to their occurrence and abundance.

\section{MATERIALS AND METHODS}

\section{Study area}

The study area encompassed the coastal surf zone of southern Brazil from Laguna, Santa Catarina state $\left(29^{\circ} \mathrm{S}, 48^{\circ} \mathrm{W}\right)$, to Chuí, Rio Grande do Sul state $\left(34^{\circ} \mathrm{S}\right.$, $53^{\circ} \mathrm{W}$ ) (Fig. 1). These coastal areas are characterized by sandy beaches exposed to wave action with a wide dissipative to intermediate surf zone (Calliari and Klein 1995). Tidal oscillations along the southern Brazilian coast are defined by their low amplitude, with an average tidal amplitude of $0.47 \mathrm{~m}$ and minimal influence on estuarine circulation (Seeliger et al. 1998).

The regional climate is temperate with well-defined seasons and is under the control of the South Atlantic anticyclone high-pressure centre. The latitudinal movement of the anticyclone centre and the passage of polar frontal systems influence and modify the seasonal cycle of the climate (Seeliger et al. 1998). These systems are responsible for dominant winds from the northeast quadrant (NE, mean speed $5 \mathrm{~m} \mathrm{~s}^{-1}$ ) throughout the year and winds from the southwest quadrant ( $\mathrm{SW}$, mean speed $8 \mathrm{~m} \mathrm{~s}^{-1}$ ) during the passage of polar frontal systems, which are common during 

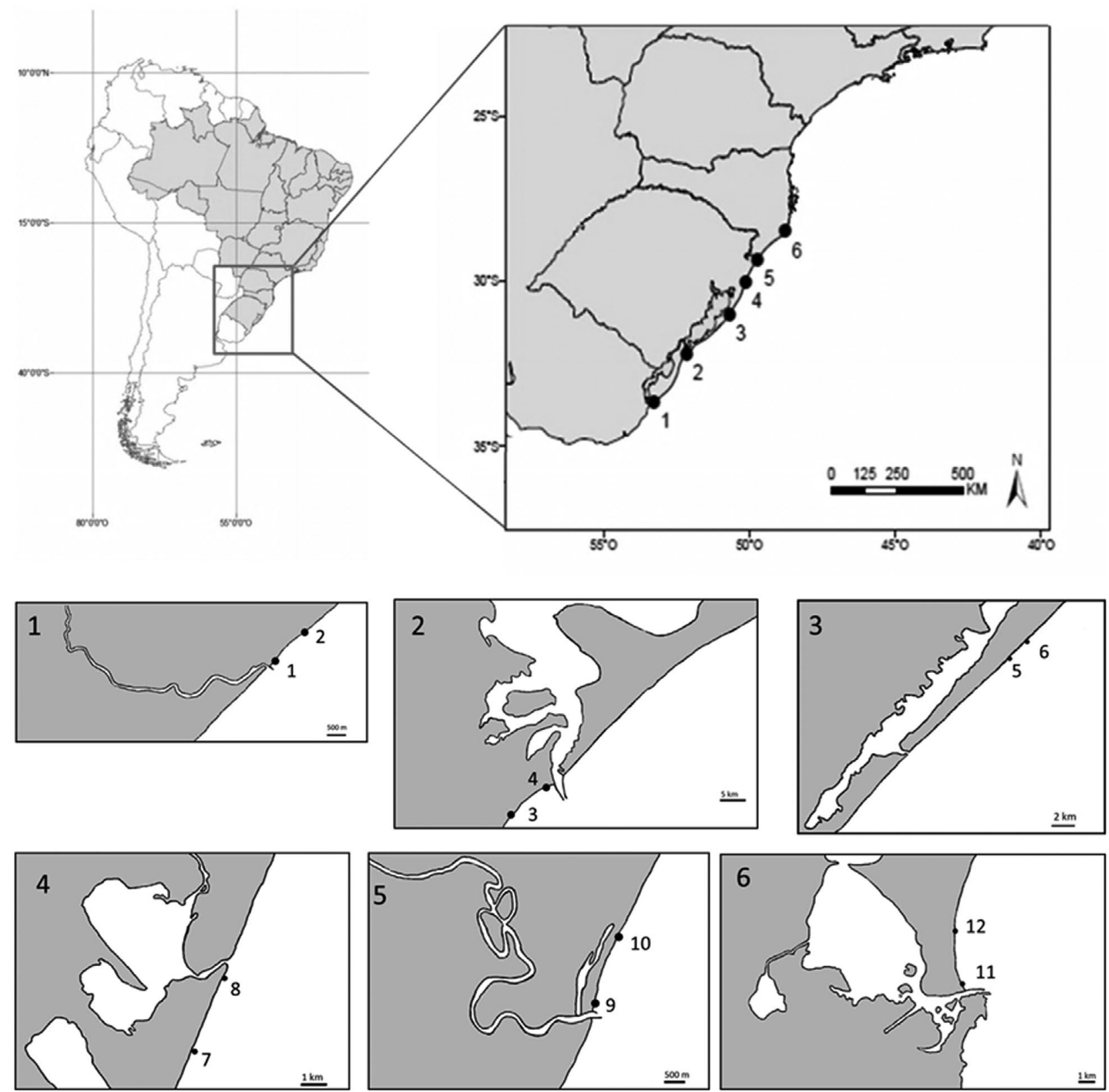

Fig. 1. - Map of the six sampling sites: Site 1, Chuí; Site 2, Rio Grande; Site 3, Mostardas; Site 4, Tramandaí; Site 5, Passo de Torres; and Site 6, Laguna. Numbers (1 to 12) represent sampling points where beach seine samples were obtained.

the winter. The mean annual rainfall (1200-1500 mm) is related to the pattern and frequency of these systems and to the effects of the El Niño-Southern Oscillation cycle (Seeliger et al. 1998).

The complex hydrographic system of the coastal plain in southern Brazil includes several lagoons and estuaries. Our study area encompassed six estuarine systems: 1) Chuí Creek $\left.\left(33.73^{\circ} \mathrm{S}\right), 2\right)$ the Patos Lagoon estuary $\left.\left(32.20^{\circ} \mathrm{S}\right), 3\right)$ the Peixe Lagoon $\left.\left(31.15^{\circ} \mathrm{S}\right), 4\right)$ the Tramandaí-Armazém Lagoon complex $\left(29.98^{\circ} \mathrm{S}\right)$, 5) the Mampituba River $\left(29.32^{\circ} \mathrm{S}\right)$, and 6) the Imaruí-Mirim-Santo Antônio Lagoon complex $\left(28.49^{\circ} \mathrm{S}\right)$ (Fig. 1, Table 1).
1) Chuí Creek, Rio Grande do Sul (RS), Brazil, is located on the border between Brazil and Uruguay. The Chuí Creek drainage basin has an area of approximately $340 \mathrm{~km}^{2}$ and an estuarine area of 0.5 $\mathrm{km}^{2}$ (Ramos and Vieira 2001). Chuí Creek arises in an area of wetlands and runs almost parallel to the coast in a southerly direction for approximately 66 $\mathrm{km}$ until it reaches the Atlantic Ocean. Chuí Creek has suffered from anthropic modifications over time, including the change in its original course, the use of its fresh water and the construction of a pair of jetties (1500 m long) in the late 1970 s to demarcate the border between Brazil and Uruguay. At low flow, the 
Table 1. - Summary of environmental variables used in the Mugil liza occurrence and abundance models.

\begin{tabular}{|c|c|c|c|c|c|c|c|c|c|c|c|}
\hline Site & $\begin{array}{l}\text { Lat.- } \\
\text { Long. }\end{array}$ & $\begin{array}{c}\text { Estuarine } \\
\text { area } \\
\left(\mathrm{km}^{2}\right)\end{array}$ & $\begin{array}{c}\text { Sampling } \\
\text { point } \\
\text { number }\end{array}$ & Tide & $\begin{array}{l}\text { Distance } \\
\text { from estuary } \\
\text { mouth }(\mathrm{km})\end{array}$ & \multicolumn{2}{|c|}{ Salinity } & \multicolumn{2}{|c|}{ Temperature $\left({ }^{\circ} \mathrm{C}\right)$} & \multicolumn{2}{|c|}{ Transparency $(\mathrm{cm})$} \\
\hline & & & & & & $\min -\max$ & $\begin{array}{c}\text { mean } \pm \\
\text { sd }\end{array}$ & $\begin{array}{l}\min - \\
\max \end{array}$ & $\begin{array}{c}\operatorname{mean} \pm \\
\text { sd }\end{array}$ & $\begin{array}{l}\min - \\
\max \end{array}$ & $\begin{array}{c}\operatorname{mean} \pm \\
\text { sd }\end{array}$ \\
\hline \multirow{2}{*}{ 1. Chuí } & \multirow{2}{*}{$\begin{array}{l}33.73^{\circ} \mathrm{S}, \\
53.36^{\circ} \mathrm{W}\end{array}$} & \multirow{2}{*}{$0.3^{\mathrm{a}}$} & 1 & \multirow{2}{*}{$0.6^{\mathrm{e}}$} & 0.3 & $24.0-30.3$ & $28.1 \pm 1.7$ & $13.2-28.0$ & $19.8 \pm 4.6$ & $10-50$ & $33.6 \pm 13$ \\
\hline & & & 2 & & 1.4 & $26.4-30.1$ & $28.5 \pm 1.2$ & $14.9-26.0$ & $20.0 \pm 4.0$ & $10-100$ & $39.0 \pm 23$ \\
\hline \multirow{2}{*}{ 2. Rio Grande } & \multirow{2}{*}{$\begin{array}{l}32.20^{\circ} \mathrm{S}, \\
52.17^{\circ} \mathrm{W}\end{array}$} & \multirow{2}{*}{$971.0^{\mathrm{a}}$} & 3 & \multirow{2}{*}{$0.47^{\mathrm{f}}$} & 8.8 & $15.8-32.6$ & $28.5 \pm 4.5$ & $12.0-28.0$ & $20.3 \pm 4.4$ & $10-60$ & $30.0 \pm 16$ \\
\hline & & & 4 & & 0.7 & $17.3-33.0$ & $28.1 \pm 4.6$ & $11.4-28.5$ & $20.1 \pm 4.5$ & $10-100$ & $40.3 \pm 23$ \\
\hline \multirow{2}{*}{ 3. Mostardas } & \multirow{2}{*}{$\begin{array}{l}31.15^{\circ} \mathrm{S}, \\
50.80^{\circ} \mathrm{W}\end{array}$} & \multirow{2}{*}{$45.0^{\mathrm{b}}$} & 5 & \multirow{2}{*}{$0.45^{\mathrm{g}}$} & 13 & $29.0-36.4$ & $32.0 \pm 2.6$ & $14.9-26.0$ & $20.2 \pm 3.1$ & $15-60$ & $31.0 \pm 17$ \\
\hline & & & 6 & & 13.9 & $29.1-37.5$ & $32.4 \pm 2.8$ & $15.2-25.7$ & $20.3 \pm 3.4$ & $10-70$ & $34.0 \pm 18$ \\
\hline \multirow{2}{*}{ 4. Tramandaí } & \multirow{2}{*}{$\begin{array}{l}29.98^{\circ} \mathrm{S}, \\
50.12^{\circ} \mathrm{W}\end{array}$} & \multirow{2}{*}{$30.0^{\mathrm{a}}$} & 7 & \multirow{2}{*}{$0.3^{\mathrm{h}}$} & 3.6 & $25.2-36.7$ & $30.9 \pm 3.0$ & $15.4-24.8$ & $20.6 \pm 2.7$ & $0-100$ & $44.6 \pm 30$ \\
\hline & & & 8 & & 0.4 & $22.6-36.9$ & $30.8 \pm 3.8$ & $15.4-25.0$ & $21.0 \pm 2.6$ & $15-70$ & $45.8 \pm 14$ \\
\hline \multirow{2}{*}{ 5. P. Torres } & \multirow{2}{*}{$\begin{array}{l}29.32^{\circ} \mathrm{S}, \\
49.71^{\circ} \mathrm{W}\end{array}$} & \multirow{2}{*}{$0.5^{\mathrm{c}}$} & 9 & \multirow{2}{*}{$0.5^{\mathrm{i}}$} & 0.2 & $6.4-37.8$ & $23.4 \pm 9.3$ & $16.6-26.0$ & $20.7 \pm 2.9$ & $20-60$ & $40.3 \pm 13$ \\
\hline & & & 10 & & 0.8 & $15.5-38.2$ & $29.8 \pm 5.0$ & $15.0-23.5$ & $20.1 \pm 3.0$ & $0-45$ & $29.1 \pm 14$ \\
\hline \multirow{2}{*}{ 6. Laguna } & \multirow{2}{*}{$\begin{array}{l}28.49^{\circ} \mathrm{S}, \\
48.76^{\circ} \mathrm{W}\end{array}$} & \multirow{2}{*}{$184.0^{\mathrm{d}}$} & 11 & \multirow{2}{*}{$0.6^{\mathrm{j}}$} & 0.3 & $28.0-36.8$ & $32.5 \pm 2.3$ & $16.1-23.0$ & $19.1 \pm 2.3$ & $35-100$ & $71.9 \pm 24$ \\
\hline & & & 12 & & 2.2 & $25.2-37.4$ & $31.9 \pm 3.2$ & $16.3-23.0$ & $19.1 \pm 2.3$ & $30-100$ & $64.6 \pm 25$ \\
\hline
\end{tabular}

Estuarine area and mouth width obtained from the literature were a (Ramos and Vieira 2001), b (Loebmann and Vieira 2005) and d (Fonseca and Netto 2006); the rest were calculated with the ArcMap tool (c). Tides were obtained from the literature: e (Hartmann and Pereira 2001), f (Seeliger et al. 1998), g (Schwarzbold and Schäfer 1984), h (Lira et al. 1976), i (D'Aquino et al. 2011) and j (Pimenta 1958).

stream has a maximum width of $100 \mathrm{~m}$ and a depth ranging between 1.5 and $3 \mathrm{~m}$. The amplitude of the astronomical tide is low $(0.5 \mathrm{~m})$ and the wind regime determines the saltwater flow into the system (Hartmann and Pereira 2001).

2) The Patos Lagoon estuary is located in Rio Grande, RS. The Patos Lagoon, with a total area of $\sim 10000 \mathrm{~km}^{2}$ (draining a large hydrological basin of $200000 \mathrm{~km}^{2}$ ), is one of the largest choked coastal lagoons in the world. It extends for $270 \mathrm{~km}$ along the coastline of southern Brazil. It was formed by multiple sand barrier complexes and can be divided into biological units. The estuarine region, with a total area of $900 \mathrm{~km}^{2}$ (approximately 10\% of the lagoon) is characterized by large shallow areas $(<2 \mathrm{~m}$ deep). The estuary is connected to the South Atlantic via a 20 $\mathrm{km}$ channel (0.5-3000 $\mathrm{m}$ in width), and the mouth is stabilized by a pair of jetties. Owing to its morphological characteristics and the proximity of an amphidromic point, the tides in the region have low amplitude (mean $0.4 \mathrm{~m}$ ). The wind patterns and precipitation in the watershed determine the salinity regime in the estuary (Seeliger et al. 1998).

3) The Peixe Lagoon is located in Mostardas, RS. It is situated in the narrow sandy strip between the Patos Lagoon and the Atlantic Ocean and was recognized as a National Park in 1986. It has an area of 34000 ha, including not only the Peixe Lagoon but also surrounding ecosystems such as beaches and small freshwater lakes. The Peixe Lagoon covers approximately $43 \mathrm{~km}^{2}$ with a depth ranging from 0.3 to $2 \mathrm{~m}$, and the lagoon has an intermittent opening to the ocean (Schwarzbold and Schäfer 1984).

4) The Tramandaí-Armazém Lagoon complex is located in Tramandaí, RS. The Tramandaí River Basin has an area of $3145 \mathrm{~km}^{2}$ and the Tramandaí River is the primary effluent. From the estuary area $\left(29^{\circ} 55^{\prime} \mathrm{S}\right.$ to $30^{\circ} 00^{\prime} \mathrm{S}$ and $50^{\circ} 06^{\prime} \mathrm{W}$ to $50^{\circ} 11^{\prime} \mathrm{W}$ ), the connection with the Atlantic Ocean is via a narrow, short channel $(55 \mathrm{~m})$ that is stabilized by a single jetty along the left margin. The amplitude of the astronomical tide in this region is low $(0.3 \mathrm{~m})$ (Lira et al. 1976).

5) The Mampituba River is located in Torres, RS, and Passo de Torres, Santa Catarina. The hydrographic basin of the Mampituba River (29 $11^{\prime}$ to $29^{\circ} 26^{\prime} \mathrm{S}$ and $49^{\circ} 42^{\prime}$ to $50^{\circ} 12^{\prime} \mathrm{W}$ ) has an area of $1224 \mathrm{~km}^{2}$ that empties into the Atlantic Ocean. The Mampituba River is small (62 km long) and has an average flow of $19 \mathrm{~m}^{3} \mathrm{~s}^{-1}$. The average depth is $4 \mathrm{~m}$ and the mouth is stabilized by a pair of jetties (north jetty, $100 \mathrm{~m}$ and south jetty, $260 \mathrm{~m}$ ). The tidal pattern is microtidal and is primarily governed by the wind regime (D'Aquino et al. 2011).

6) The Imaruí-Mirim-Santo Antônio Lagoon complex is located in Laguna, Santa Catarina. The lagoon system has an area of approximately $220 \mathrm{~km}^{2}$ and has the Tubarão River as its main tributary. The communication between the lagoon system and the ocean oc- 
curs through a fixed bar in the Santo Antônio Lagoon that is approximately $200 \mathrm{~m}$ wide and $1200 \mathrm{~m}$ long. The tide is of low amplitude, and hydrodynamics are primarily governed by the wind (Pimenta 1958).

\section{Fish sampling and environmental variables}

The fish were collected monthly between June 2011 and May 2012 in the surf zones adjacent to the mouths of the six estuaries (Fig. 1). Two marine surf zone sampling points, starting at $500 \mathrm{~m}$ from the jetties and spaced 1 to $6 \mathrm{~km}$ apart from each other, were selected at each site (Fig. 1). At each of the 12 sampling points we collected five samples monthly. Each beach seine sample was conducted perpendicular to the beach at a depth of $1.5 \mathrm{~m}$. The beach seine net was $9 \mathrm{~m}$ long and $1.5 \mathrm{~m}$ high with a $13 \mathrm{~mm}$ knot-to-knot mesh in the wings and a $5 \mathrm{~mm}$ knot-to-knot mesh in the $3 \mathrm{~m}$ central section. Each haul covered an area of approximately $120 \mathrm{~m}^{2}$. The fish caught were held on ice and subsequently processed in the laboratory. Mullet abundance was calculated as the catch per unit effort (CPUE), i.e. the total number of individuals per haul.

Water temperature $\left({ }^{\circ} \mathrm{C}\right)$ and salinity were recorded monthly at each sampling point using a digital multiparameter probe. The salinity was measured using the Practical Salinity Scale (PSU). The water transparency was measured using a Secchi disc $(\mathrm{cm})$. Additional$\mathrm{ly}$, the estuarine area (the area, $\mathrm{km}^{2}$ ) and mouth width (width, $\mathrm{km}$ ) of each of the six estuaries, the distance of each sampling point from the mouth of the adjoining estuary (distance, $\mathrm{km}$ ), and the distance from each sampling point to the $M$. liza theoretical spawning area as defined by Lemos et al. 2014 (distance to the spawning area, $\mathrm{km}$ ) were also included in the analyses. Tides, estuarine area and width were obtained from the literature (Table 1); the other distances were determined using the ArcMap 10.0 tool.

This study was conducted in accordance with the recommendations of the Brazilian Ministry of the Environment (MMA), and all data collection and fish handling were endorsed by the Permanent Licence for Collection of Zoological Material (Number: 10125-2) granted to JPV since September 2007. There was no experimentation in the present work.

\section{Data analysis}

A one-way ANOVA was performed to test temporal differences in environmental variables among sites and differences in mullet abundance between sampling points at each site. This analysis was also used to test the significances of differences in abundance of mullets $\leq 30 \mathrm{~mm}$ TL and mullets $>30 \mathrm{~mm}$ TL between sites. Temporal differences in abundance of mullets $\leq 30 \mathrm{~mm}$ TL (CPUE) between sites (six levels) and months (12 levels) of the year were tested by a two-way ANOVA. Tukey post hoc tests were conducted to evaluate the paired comparisons that were significantly different. We used a non-metric multidimensional scaling (nMDS) plot to visualize the environmental factors and potential differences between sampling sites, from
A

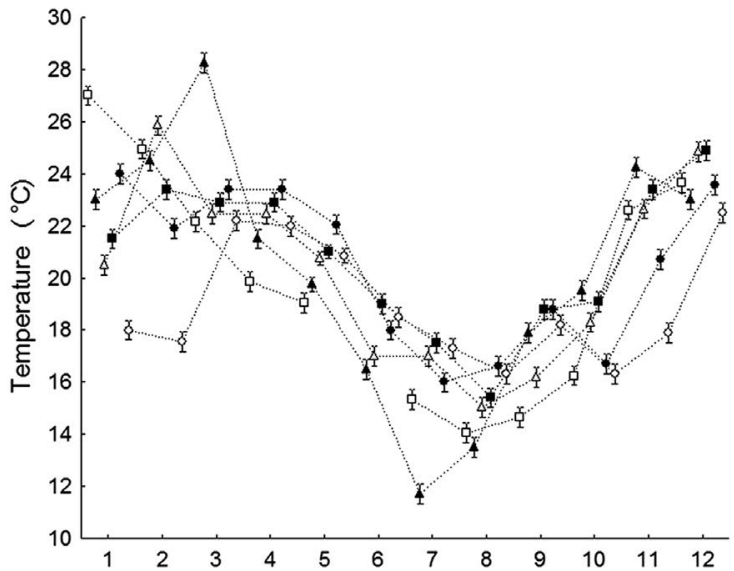

B

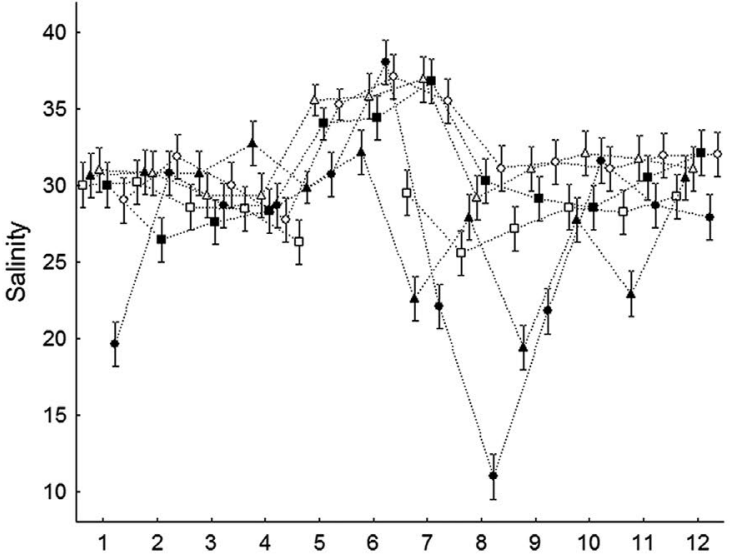

C

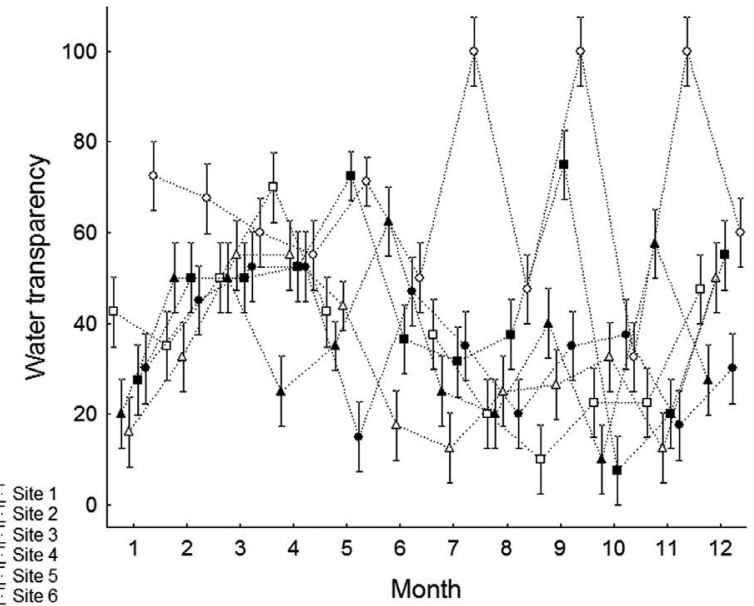

Fig. 2. - Temporal fluctuations in environmental variables (A) surface water temperature; (B) salinity; (C) transparency, of each sampling site: Site 1, Chú́; Site 2, Rio Grande; Site 3, Mostardas; Site 4, Tramandaí; Site 5, Passo de Torres; and Site 6, Laguna. Error bars $=$ standard error of the mean.

dissimilarity matrix of calculating the Euclidean distances.

The relationships between the abundance of young mullets and the selected environmental variables were evaluated using generalized linear models (GLMs). Prior to the statistical analysis, a pairwise correlation matrix was constructed using Spearman's rank corre- 


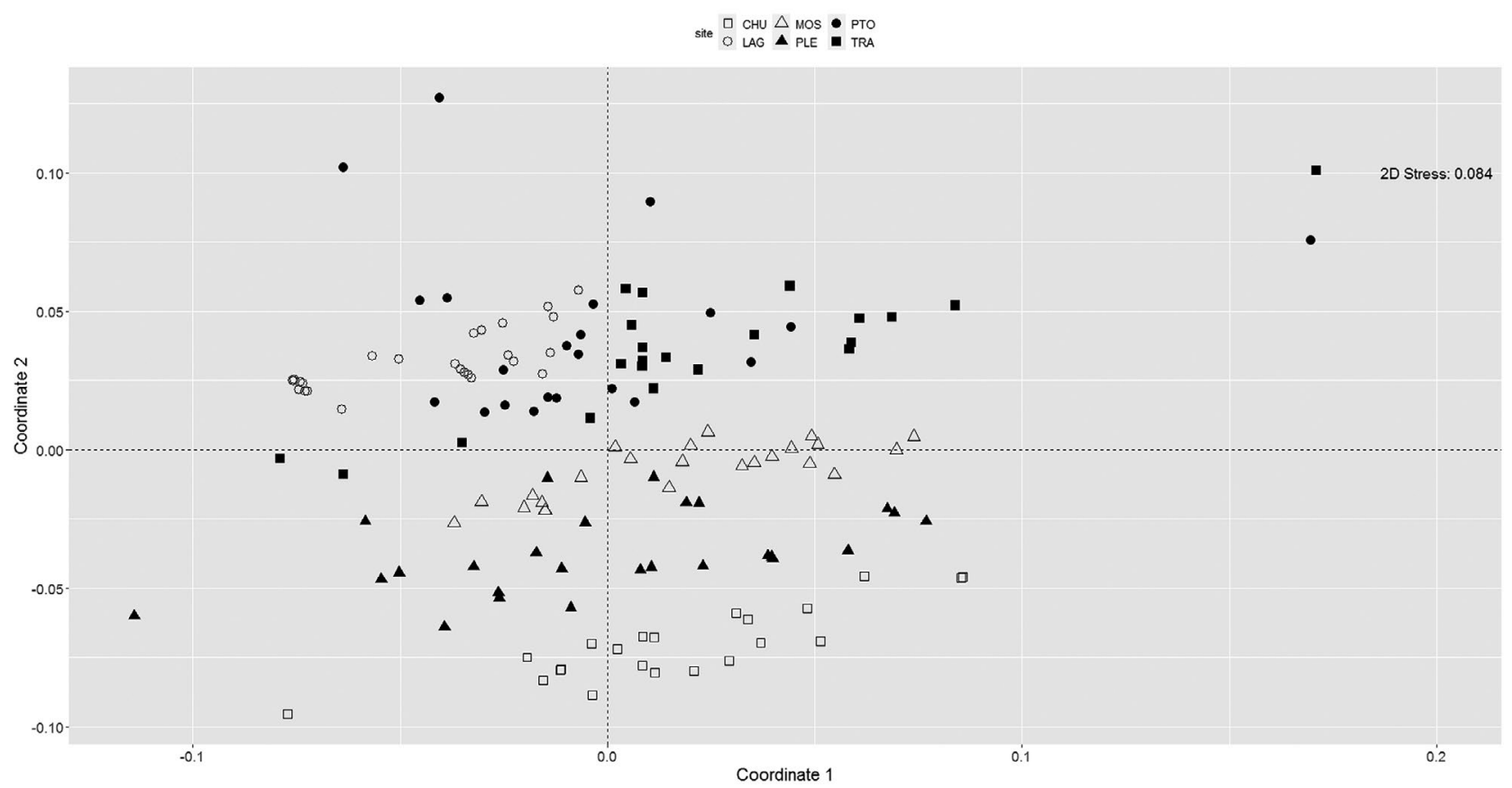

Fig. 3. - Non-metric multidimensional scaling (nMDS) ordination plot based on Euclidean distances matrix illustrating differences among sampling sites. Site 1, Chuí; Site 2, Rio Grande; Site 3, Mostardas; Site 4, Tramandaí; Site 5, Passo de Torres; and Site 6, Laguna. Stress of analysis $=0.084$

lation coefficients to identify and prevent possible collinearities among abiotic variables. Significant correlations were observed between some variables $(p<0.05$, $\left.r_{s}>0.8\right)$. Based on these results, eight explanatory variables were selected for inclusion in GLMs: month, sampling site, estuary area, estuary distance, tide, salinity, temperature and water transparency. Due to the high occurrence of zeros (40\%) in the abundance data, two models were constructed: the first evaluated presence/ absence of $M$. liza and the second assessed the positive abundances (beach seine samples with an occurrence of at least one $M$. liza individual). The first model esti- mated the probability of $M$. liza occurrence in the surf zone sampled (using $M$. liza presence as a response variable) using a logistic regression model with a log link function. The GLM used to model $M$. liza presence considered presence/absence ( 0 or 1 values) as the response variable and used the binomial family for the probability distribution of the error. The GLM used to model $M$. liza abundance used the log-transformed CPUE $(\log (\mathrm{x}+1))$ as the response variable with a log link function, and the Gamma family was used for the probability distribution. A significant interaction between the month and the sampling point location was

Table 2. - Total number and total length (TL in $\mathrm{mm}$ ) range of Mugil liza sampled and percentage frequency of the size classes at each study site. The sampling effort was the same at all sites.

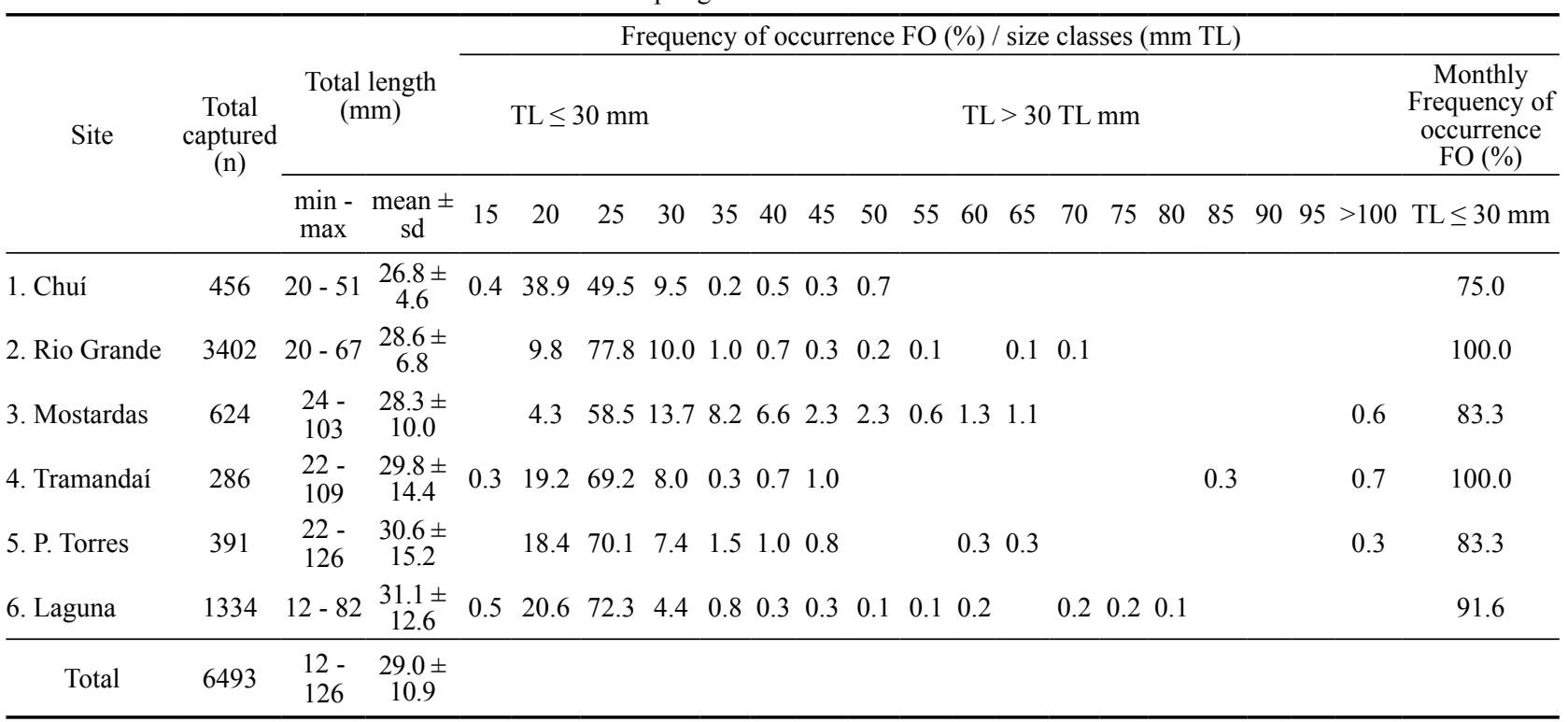


observed in a preliminary analysis $(\mathrm{p}<0.05)$, and an interaction term between the month and the sampling point was therefore included in all models.

The best model was selected according to the method described by Rodrigues et al. (2015). The drop1 function was used to compare the full model with the reduced model, from which the interaction was eliminated using the chi-squared test. Stepwise selection was used to select the variables included in the final models and to rank them from most to least significant. All models were tested for overdispersion. The best final combination of variables was selected using the chi-squared test, the Akaike information criterion (AIC) and graphical residual analysis. The final model included only the significant variables. For each model, the relative contribution of each variable to the model was evaluated by comparing the percent deviance explained. A significance level of 0.05 was adopted for all statistical procedures, and all statistical procedures were performed using $\mathrm{R}$ software ( $\mathrm{R}$ Development Core Team 2013).

\section{RESULTS}

Significant differences in salinity (ANOVA, $\mathrm{F}=22.69 ; \mathrm{p}<0.05$ ), temperature (ANOVA, $\mathrm{F}=10.74$; $\mathrm{p}<0.05$ ) and water transparency (ANOVA, $\mathrm{F}=19.06$ $\mathrm{p}<0.05)$ were observed between sites and months over the study period (Fig. 2). The mean values of seawater surface temperature differed among the six sampling sites but showed seasonal fluctuations with a clear annual cycle: they declined steadily from April to August (monthly average $21^{\circ} \mathrm{C}-13.5^{\circ} \mathrm{C}$ ), and thereafter the monthly average temperature increased to $18.5^{\circ} \mathrm{C}$ by September (Fig. 2A). Site 2 (Rio Grande) had higher temperatures in the warmer months and lower temperatures in the colder months. Site 6 (Laguna) had lower temperatures in the warmer months (Fig. 2A). Salinity showed no seasonal pattern (Fig. 2B). The lowest salinity values were recorded at Sites 5 (Passo de Torres) and 6 (Laguna) (the lowest salinity value was recorded in August at Site 5). The highest salinities were found from May to July (Fig. 2B). Significant differences were observed among sampling sites for water transparency, and sampling Site 6 (Laguna) showed the highest water transparency values in January, February, June, September and November (Fig. 2C). The nMDS plot was used to compare the similarity in the environmental factors of sampling sites. It is possible to observe three groups in the nMDS plot: Site 1 (Chuí), separated from the other sites; Sites 2 (Rio Grande) and 3 (Mostardas); and Sites 4 (Tramandaí), 5 (Passo de Torres) and 6 (Laguna) (Fig. 3).

A total of $6493 \mathrm{M}$. liza individuals were captured (Table 2). Significant differences in the number of individuals captured per beach seine sample (CPUE) were observed between the collection sites. Rio Grande (Site 2) had the highest abundance of $M$. liza (CPUE $=26.4$ individuals/haul; ANOVA, F=4.98, $\mathrm{p}<0.05$ ), representing more than $52 \%$ of the total of individuals caught at the six collection sites. No significant differences in abundance were observed among the remaining

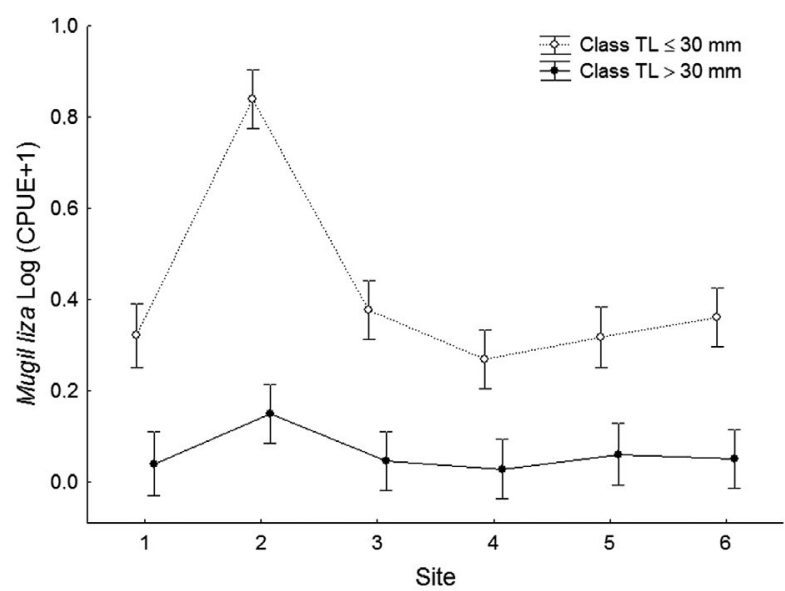

Fig. 4. - Mugil liza juvenile abundance (Log (CPUE+1)) among the collection sites: Site 1, Chuí; Site 2, Rio Grande; Site 3, Mostardas; Site 4, Tramandaí; Site 5, Passo de Torres; and Site 6, Laguna. Error bars, standard error of the mean; TL, total length (mm).

sites; 1) Chuí, 3) Mostardas, 4) Tramandaí, 5) Passo de Torres, and 6) Laguna (ANOVA, $\mathrm{F}=10.73$, $\mathrm{p}>0.05$ ). Among the 12 sampling points, only points 3 and 4 (Site 2, Rio Grande) showed significant differences in mullet abundance (ANOVA, $\mathrm{F}=14.15 ; \mathrm{p}<0.05$ ).

The size distribution of the $M$. liza individuals varied between $12 \mathrm{~mm}$ and $126 \mathrm{~mm}$ TL. Individuals 30 $\mathrm{mm}$ TL were more abundant than larger individuals $(\mathrm{TL}>30 \mathrm{~mm}$ ) at all sites (ANOVA, $\mathrm{F}=13.050, \mathrm{p}<0.05$ ) (Fig. 4). At all sites, the total number of individuals from classes 15 to $30(\leq 30 \mathrm{~mm}$ TL) represented more than $96 \%$ of all mullets collected, with the exception of Site 3 (Mostardas), where they represented 77\% (Table 2). Individuals in size class $15 \mathrm{~mm}$ TL (10 to $15 \mathrm{~mm}$ TL) occurred occasionally at Chuí (Site 1), Tramandaí (Site 4) and Laguna (Site 6), but individuals from size class $25 \mathrm{~mm}$ TL were the modal length at all sampling sites (Table 2). Mullets $\leq 30 \mathrm{~mm}$ TL occurred in all 12 months sampled at Sites 2 and 4 and were present among 9 to 11 of all months sampled at the other sampling sites (Table 2).

The best model for presence/absence of young mullets (i.e. lower AIC) included three significant variables (site, month and water temperature). Those variables explained $33.5 \%$ of the total deviance of the model. The water temperature alone explained more than half of the total deviance $(23 \%)$ (Table 3$)$. Young mullets were present in all seasons, but the probability of occurrence was higher in winter (May to July) and was associated with low temperatures (Fig. 5A, B). The highest probability of occurrence of young mullets was observed at Site 2 (Rio Grande) (Fig. 5C). The best GLM for the abundance data of $M$. liza included three explanatory variables, sampling site, month and water temperature (Table 3), and explained $39 \%$ of the total deviance of the model. Similar to the GLM model for presence/absence, the abundance GLM model showed that water temperature was responsible for more than half of the explained deviance $(21 \%)$. Young mullets were observed in the surf zone in all months, and abundance was a positive 

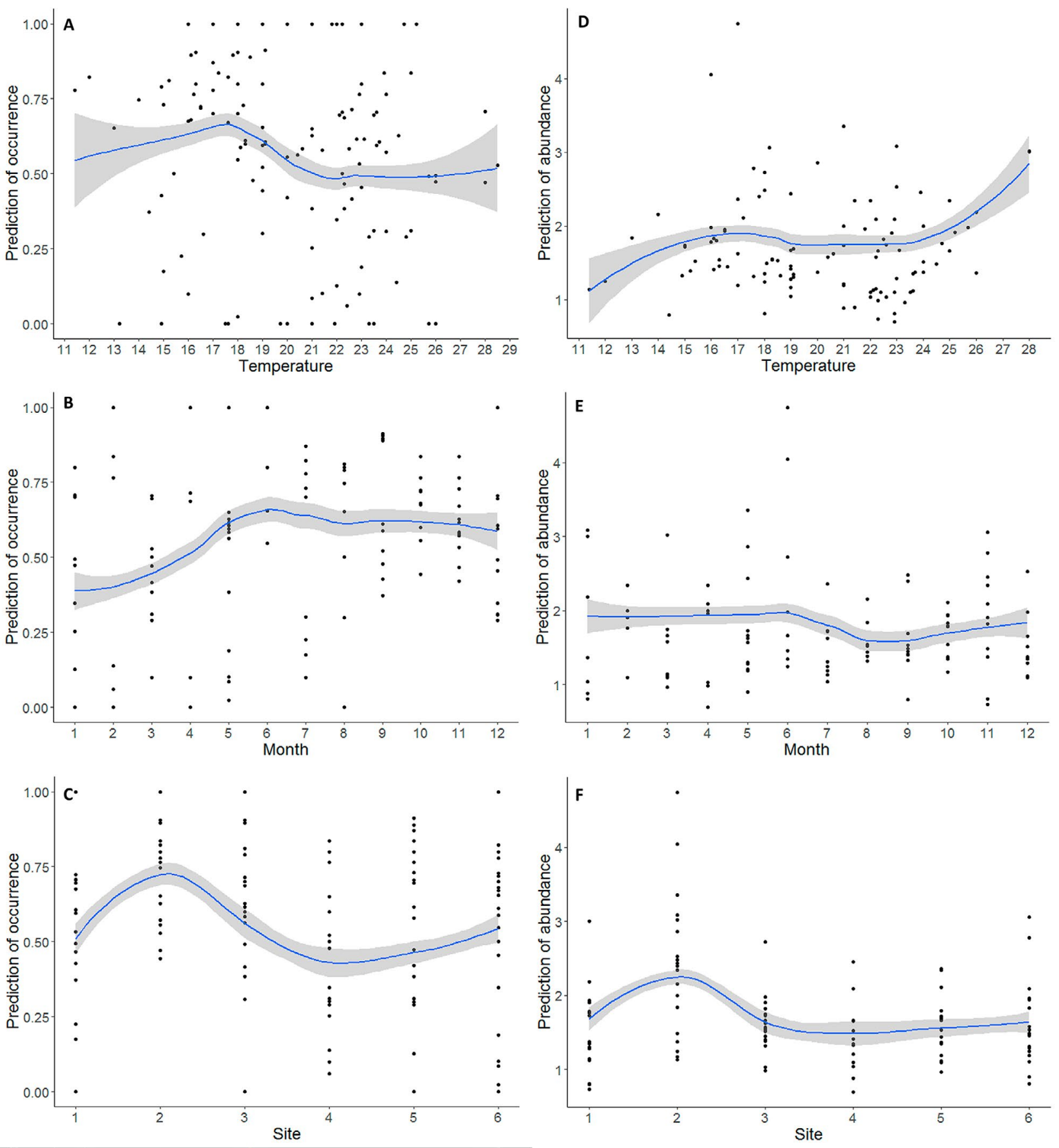

Fig. 5. - Relations between significant variables in the GLM models and mullet occurrence and abundance. Prediction of occurrence: (A) temperature, (B) month and (C) sampling site. Prediction of abundance (CPUE): (D) temperature, (E) month and (F) sampling site. Site 1, Chuí; Site 2, Rio Grande; Site 3, Mostardas; Site 4, Tramandaí; Site 5, Passo de Torres; and Site 6, Laguna.

relationship of temperature (Fig. 5D, E). Mullet abundance was highest at Site 2 (Rio Grande) (Fig. 5F).

\section{DISCUSSION}

Surf zone habitats form a productive ecosystem, serving important functions as nursery areas, major fishery zones and migratory pathways. The importance of this area for species dependent on the estuary has long been known (Whitfield 1989). Vieira (1991) pro- posed a model for the early life history of $M$. liza in southern Brazil, suggesting that young individuals use the surf zone temporarily after the larval neustonic life stages and before recruitment to the estuarine environment. Young mullets remain present throughout the year in the surf zone over the entire sampling area. The surf zone is therefore an important environment for young mullets, and long periods in these areas could provide better opportunities for young mullets to find and penetrate estuaries. 
The recruitment to estuaries of species that spawn at sea has two major phases (Boehlert and Mundy 1988). The first is the arrival at and movement through the coastal zone. This phase is associated with physical factors responsible for the passive transport of organisms, such as tides, oceanographic fronts and coastal currents (Boehlert and Mundy 1988). The longshore currents in the study region follow the seasonal wind pattern. Strong winds from the south and southwest predominate between April and August (especially during the passage of cold fronts), causing strong currents towards the northeast (Seeliger et al. 1998). The importance of this wind pattern for the reproductive migration of adult individuals is already known (Lemos et al. 2014). However, during most of the year (September to March), there is a predominance of northeast winds and coastal currents with low intensity but high frequency towards the southwest (Tozzi and Calliari 2000). These coastal currents can be important for the transport of young mullets along the coast towards the south.

The second phase of recruitment to estuaries is the aggregation of individuals near estuary mouths (Boehlert and Mundy 1988). Many of important commercial fish species recruit in estuaries, presumably in response to certain olfactory cues transported into the marine environment from either estuarine or freshwater sources (Wasserman and Strydom 2011). A strong aggregation of juvenile mugilids was observed in response to the presence of estuarine discharges in surf zones (Strydom 2003). In southern Brazil, Rodrigues et al. (2015) observed a positive effect of the weaker morphodynamics and the occurrence of an estuarine plume at the beach on the abundance of $M$. liza juveniles in the surf zone. Several environmental and ecological attributes were assessed in the present study to explain the occurrence and abundance of young mullets in the surf zone, and the abundance near the Patos Lagoon estuary mouth (Site 2) was significantly higher than that at the other sites sampled. The Patos Lagoon is the largest estuary in the study area, and the plume is related to the size of the drainage basin and the high discharge of the lagoon, which are important factors for the high sediment input into the adjacent coastal zone (Figueiredo and Calliari 2006). In contrast, the sediment input via estuarine discharge was not significant at the beaches adjacent to the Mampituba River, the Tramandaí-Armazém Lagoon Complex and Chuí Creek (Figueiredo and Calliari 2006). Although water salinity and transparency were not important factors in explaining the occurrence and availability of young $M$. liza throughout the study area, the sediment input via estuarine discharge can be an important factor for explaining the greater abundance and occurrence of young mullet near the mouth of Patos Lagoon.

The best models for presence/absence and for abundance of young mullets demonstrate that temperature was the factor that most contributed to the explanation of variance. However, temperature showed a negative relationship with the occurrence and a positive relationship with the abundance of young mullet in the study area. Young mullets were present in all seasons, but the probability of presence was higher in winter (May to July) and was associated with low temperatures. This can be explained by the reproductive migration of M. liza, which occurs at the end of the austral autumn and the beginning of the austral winter (from April to July), and the occurrence of one peak spawning in June between northern Santa Catarina and Paraná $\left(26^{\circ} \mathrm{S}\right)$ (Lemos et al. 2014). Similar to the GLM model for presence/absence, the GLM model for abundance showed that the water temperature was responsible for more than half of the explained deviance, but mullet abundance was positively associated with temperature. The abundance of young mullets remained at the same level over a wide temperature range, between $16^{\circ} \mathrm{C}$ and $24^{\circ} \mathrm{C}$.

Juveniles of $M$. liza have been observed to remain in the surf zone for long periods in southern Brazil and Argentina (Acha 1990, Vieira 1991, Castellini et al. 2017). The specific size at which the mullets start to appear in surf zones and enter estuaries varies between authors (González-Castro and Minos 2016). In the present study, we observed that individuals smaller than 15 $\mathrm{mm}$ TL occur occasionally throughout the study area. However, individuals $\leq 30 \mathrm{~mm}$ TL represented more than $96 \%$ of all mullets collected (with the exception of Site 3, where they represented 77\%) and were present in the surf zone at least 9 of the 12 months of the year. This result is in accordance with Vieira (1991), who demonstrated that after reaching approximately $20 \mathrm{~mm}$ TL, the young $M$. liza gradually migrate to the bottom in the surf zone and begin to feed on benthic organisms

Table 3. - Analyses of deviances for the best generalized linear model obtained to explain the occurrence and abundance of the mullet Mugil liza. AIC, Akaike information criterion; Res. Dev., residual deviance; Dev. Expl., deviance explained in percentage; Sig., significance; *, $\mathrm{p}<0.05 ; * *, \mathrm{p}<0.01 ; * * *, \mathrm{p}<0.001$, positive $(+)$ and negative $(-)$ slope.

\begin{tabular}{|c|c|c|c|c|c|c|}
\hline & Introduced variables & AIC & Res. Dev. & Dev. Expl. & Sig. & Slope \\
\hline \multirow[t]{5}{*}{ Occurrence (binomial model) } & $\sim($ site $\times$ month $)+$ Temperature & 829.5 & & & & \\
\hline & Null (occurrence $\sim 1$ ) & 1032.3 & 1030.3 & & & \\
\hline & $\sim$ site: month & & 924.6 & 10.5 & $*$ & - \\
\hline & - temperature & & 691.9 & 23.0 & $* * *$ & + \\
\hline & Total explained & & & 33.5 & & \\
\hline \multirow[t]{5}{*}{ Abundance (Gamma model) } & $\sim($ site $\times$ month $)+$ temperature & 1041.0 & & & & \\
\hline & Null (abundance $\sim 1$ ) & 1129.5 & 147.7 & & & \\
\hline & $\sim$ site: month & & 122.7 & 17.4 & $* * *$ & - \\
\hline & + temperature & & 91.6 & 21.6 & $* * *$ & + \\
\hline & Total explained & & & 39.0 & & \\
\hline
\end{tabular}


and mineral particles. At this stage, individuals occupy the surf zone before recruitment to the estuarine environment (Vieira 1991).

From the larvae to juvenile stage, the feeding habits change from zooplanktophagous to iliophagous (Acha 1990, Vieira 1991). The surf zone occurrence of young mullets appears to be less important at beaches with strong morphodynamics, and in this situation the change in feeding habits seems to occur inside the estuaries (Blaber and Whitfield 1977). The coastal zone in our study area is characterized by an extensive dissipative beach (Calliari and Klein 1995, Ramos and Vieira 2001), and at dissipative beaches the transition between feeding habits may occur slowly and in the surf zone (Blaber and Blaber 1980). Considering that M. liza in southern Brazil show only one peak of spawning in June and young mullets occur year-round, it is possible that the young mullets that remained in the surf zone exhibited a lower growth rate than those that were already recruited to the estuary. Thus, long periods in the surf zone could provide better opportunities for young mullets to find and penetrate estuaries, but this would imply lower growth rates. However, comparative studies with different salinities (surf zone and estuarine areas) must be performed to analyse the available information on the biology and physiology of the young stages of $M$. liza.

Acha (1990) and Castellini et al. (2017) also reported young mullets along the Argentinian coast throughout the year. González-Castro et al. (2011) described a strong reproductive period in the austral winter (AprilMay), similar to that reported for southern Brazil, and a second period in the austral summer (November-December), which was not observed by Lemos et al. (2014) in southern Brazil. Those two periods of reproduction were used by Castellini et al. (2017) to explain the occurrence of young mullets with a minimum size of between 19 and $33 \mathrm{~mm}$ SL along the Argentinian coast throughout the year. However, Lemos et al. (2014) reviewed and described the reproductive biology of $M$. liza in southern Brazil and showed that the peak in the gonadosomatic index (IG) values for females caught in marine waters (by industrial purse seine fisheries) occurred in June (mean \pm sd $\left.\mathrm{IG}_{+}=11.5 \pm 3.1\right)$ and was closely related to the presence of hyaline oocytes. The gonadosomatic index values for fish caught in Argentina are lower (4 to 6) according to González-Castro et al. (2011), who did not identify the presence of hyaline oocytes. The hydration phase during final maturation appears to be important in the production of pelagic (buoyant) mullet eggs, and the presence of hyaline oocytes has been associated with high salinity and sea surface temperatures of 19 to $21^{\circ} \mathrm{C}$ (Lemos et al. 2014). Recently, Morado et al. (2021) describes a second breeding period in the summer for the mullet $M$. liza in a Brazilian tropical bay (Sepetiba Bay coast of the State of Rio de Janeiro). The summer spawning was not foreseen in the biological literature for this place, but the local ecological knowledge of artisanal fishermen associated this spawning season with a possible resident population (Morado et al. 2021). More studies must be carried out to support the hypothesis of a local summer spawning event in southern Brazil.
In summary, the results of our study demonstrate that the probability of occurrence of young M. liza throughout the sampling area is higher in winter (May to July) and associated with low temperatures; however, young mullets remain present throughout the year in the surf zone over the entire sampling area. Site 2, adjacent to the Patos Lagoon estuary, had the highest probability of occurrence of all collection sites and the greatest abundance $(n=3402)$ of young $M$. liza, which represented $52 \%$ of the total of individuals $(n=6493)$ caught among the six sites sampled. Although other estuaries along the southern Brazilian coast are also used by mullets as nursery grounds (Ramos and Vieira 2001, Loebmann et al. 2005, Favero and Dias 2015), our results indicate that the Patos Lagoon estuary can be considered the largest nursery area for the southern population of $M$. liza, and corroborate the perception of local fishermen that Patos Lagoon is the largest nursery area for M. liza (Herbst and Hanazaki 2014). Comparative studies between surf zone and estuary growth rates, based on daily increment growth in otoliths, morphological development and changes in feeding habits in the $M$. liza ontogeny, should be performed to support some of the hypotheses raised in this work.

\section{ACKNOWLEDGEMENTS}

The authors thank the National Council for Scientific and Technological Development (CNPq), the Coordination for the Improvement of Higher Education Personnel (CAPES), the Brazilian LongTerm Ecological Research Programme (PELD-ELPA) and the Institute of Oceanography (IO-FURG). This work benefited from financial support provided by the CNPq (Proces. No. 406563/2012-8), the PELD (CNPq/PELD 34/2012 and CNPq/Capes/ FAPs/BC-Fundo Newton 15/2016) and the CAPES (process A101/2013). VML currently has a postdoctoral fellowship from the CAPES (Proces. No. 88887.461550/2019-00) and JPV has received a grant from the CNPq (process 482236/2011-6).

\section{REFERENCES}

Acha E.M. 1990. Estudio anatômico-ecologico de la lisa (Mugil liza) durante su primer año de vida. Frente. Marit. 7: 37-43.

Blaber S.J.M., Blaber T.G. 1980. Factors affecting the distribution of juvenile estuarine and in shore fish. J. Fish. Biol. 17: $143-162$. https://doi.org/10.1111/j.1095-8649.1980.tb02749.x

Blaber S.J.M., Whitfield A.K. 1977. The feeding ecology of juvenile mullet (Mugilidae) in southeast African estuaries. Biol. J. Linn. Soc. 9: 277-284. https://doi.org/10.1111/j.1095-8312.1977.tb00270.x

Boehlert G.W., Mundy B.C. 1988. Roles of behavioral and physical factors in larval and juvenile fish recruitment to estuarine nursery areas. In: American Fisheries Society Symposium 3: 1-67.

Calliari L.J., Klein A.H.F. 1995. Variabilidade das praias oceânicas entre Cassino e Chuí, RS. IO/USP. 11: 55-63.

Castellini D.L., Brown D., Lajud N.A., et al. 2017. Juveniles recruitment and daily growth of the southern stock of Mugil liza (Actinopterygii; Fam. Mugilidae): new evidence for the current life-history model. J. Mar. Biol. Assoc. U.K. 99: 204-215.

https://doi.org/10.1017/S0025315417001904 
D' Aquino C.D.A.,Andrade Neto J.S.D., Barreto G.A.M., Schettini C.A. 2011. Caracterização oceanográfica e do transporte de sedimentos em suspensão no estuário do Rio Mampituba, SC. Rev. Bras. Geofis. 29: 217-230. https://doi.org/10.1590/S0102-261X2011000200001

de Abreu-Mota M.A., Medeiros R.P., Noernberg M.A. 2018. Resilience thinking applied to fisheries management: perspectives for the mullet fishery in Southern-Southeastern Brazil. Reg. Environ. Change 18: 2047-2058. https://doi.org/10.1007/s10113-018-1323-9

Favero J.M. del, Dias J.F. 2015. Juvenile fish use of the shallow zone of beaches of the Cananéia - Iguape coastal system, southeastern Brazil. Braz. J. Oceanogr. 63: 103-114. https://doi.org/10.1590/S1679-87592015081806302

Figueiredo S.A.D., Calliari L.J. 2006. Sedimentologia e suas implicações na morfodinâmica das praias adjacentes às desembocaduras da linha de costa do Rio Grande do Sul. Gravel. 4: 73-87.

González-Castro M., Minos G. 2016. Sexuality and reproduction of Mugilidae. In: Crosetti D., Blaber S. (eds) Biology, ecology and culture of mullets (Mugilidae). CRC Press. Boca Raton. pp. 227-263.

González-Castro M., Macchi G.J., Cousseau M.B. 2011. Studies on reproduction of the mullet Mugil platanus Günther, 1880 (Actinopterygii, Mugilidae) from the Mar Chiquita coastal lagoon, Argentina: similarities and differences with related species. Ital. J. Zool. 78: 343-353. https://doi.org/10.1080/11250003.2010.549154

Hartmann C., Pereira L.E. 2001. Arroio Chuí: influencia antrópica na manutenção de um ambiente estuarino. Uberlândia, Sociedade e Natureza 13: 27-36.

Heras S., Maltagliati F., Fernández M.V., Roldán M.I. 2016. Shaken not stirred: A molecular contribution to the systematics of genus Mugil (Teleostei, Mugilidae). Integr. Zool. 11: 263-281 https://doi.org/10.1111/1749-4877.12173

Herbst D.F., Hanazaki N. 2014. Local ecological knowledge of fishers about the life cycle and temporal patterns in the migration of mullet (Mugil liza) in Southern Brazil. Neotrop. Ichthyol. 12: 879-890. https://doi.org/10.1590/1982-0224-20130156

Lemos V.M., Varela Jr. A.S., Schwingel P.R., et al. 2014. Migration and reproductive biology of Mugil liza (Teleostei : Mugilidae) in south Brazil. J. Fish. Biol. https://doi.org/10.1111/jfb.12452

Lemos V.M., Troca D.F.Á., Castello J.P., Vieira J.P. 2016. Tracking the southern Brazilian schools of Mugil liza during reproductive migration using VMS of purse seiners. Lat. Am. J. Aquat. Res. 44: 238-246. https://doi.org/10.3856/vol44-issue2-fulltext-5

Lemos V.M., Monteiro-Neto C. Cabral H., Vieira J.P. 2017. Stock identification of tainha (Mugil liza) by analyzing stable carbon and oxygen isotopes in otoliths. Fish. Bull. 115: 201-206. https://doi.org/10.7755/FB.115.2.7

Lira L., Martins I., Araujo T.H., Dehnardt E.A. 1976. Nota prévia sobre o comportamento da cunha salina no Estuário de Tramandaí RS. Ciências Biológicas 3: 115-126.
Loebmann D., Vieira J.P. 2005. Distribuição espacial e abundância das assembléias de peixes no Parque Nacional da Lagoa do Peixe, Rio Grande do Sul, Brasil. Ver. Bras. Zool. 22: 667-675. https://doi.org/10.1590/S0101-81752005000300023

Mai A.C.G., Minõ C.I., Marins L.F.F., et al. 2014. Microsatellite variation and genetic structuring in Mugil liza (Teleostei: Mugilidae) populations from Argentina and Brazil. Est. Coast. Shelf. Sci. 149: 80-86. https://doi.org/10.1016/j.ecss.2014.07.013

Mai A.C.G., Albuquerque C.Q. Lemos V.M., et al. 2019. Coastal zone use and migratory behavior of the southern population of Mugil liza in Brazil. J. Fish. Biol. https://doi.org/10.1111/jfb.14120

Martin F.D., Drewry G.E. 1978. Development of fishes of the Mid-Atlantic Bight. U.S. Dept. Inter., Fish and Wildl. Serv.

McLachlan A., Brown A. 2006. The Ecology of Sandy Shores. Academic Press, $392 \mathrm{pp}$

Morado C.N., de Andrade-Tubino M.F., Araújo F.G. 2021. Local ecological knowledge indicates: There is another breeding period in the summer for the mullet Mugil liza in a Brazilian tropical bay. Ocean. Coastal. Manage. 205: 105569. https://doi.org/10.1016/j.ocecoaman.2021.105569

Pimenta J. 1958. A faixa costeira meridional de Santa Catarina. Boletim no. 176, Rio de Janeiro: Divisão de Geologia e Mineralogia do DNPM.

R Development Core Team. 2013. Lang Environ Stat Comput 55: 275-286 Available at http://www.R-project.org

Ramos L.A., Vieira J.P. 2001. Composição específica e abundância de peixes de zonas rasas dos cinco estuários do Rio Grande do Sul, Brasil. Bol. Inst. Pesca. 27: 109-121.

Rodrigues F.L., Cabral H., Vieira J.P. 2015. Assessing surf zone fish assemblage variability in southern Brazil. Mar. Freshwater. Res. 66: 106-119. https://doi.org/10.1071/MF13210

Schwarzbold A., Schäfer A. 1984. Gênese e Morfologia das Lagoas Costeiras do Rio Grande do Sul-Brasil. Amazoniana 9: $87-104$

Seeliger U., Odebrecht C., Castello J.P. 1998. Os Ecossistemas Costeiro e Marinho do Extremo Sul do Brasil. Ed. Ecoscientia, Rio Grande, 337 pp.

Strydom N.A. 2003. Occurrence of larval and early juvenile fishes in the surf zone adjacent to two intermittently open estuaries, South Africa. Environ. Biol. Fish. 66: 349-359. https://doi.org/10.1023/A:1023949607821

Tozzi H.D.M., Calliari L.J. 2000. Morfodinâmica da praia do Cassino, RS. Pesquisas em Geociências 27: 29-42. https://doi.org/10.22456/1807-9806.20176

Vieira J.P. 1991. Juvenile mullets (Pisces: Mugilidae) in the Estuary of Lagoa dos Patos, RS, Brazil. Copeia 409-418. https://doi.org/10.2307/1446590

Wasserman R.J., Strydom N.A. 2011. The importance of estuary head waters as nursery areas for young estuary-and marine-spawned fishes in temperate South Africa. Est. Coast. Shelf. Sci. 94: 56-67. https://doi.org/10.1016/j.ecss.2011.05.023

Whitfield A.K. 1989. Ichthyoplankton in a southern African surf zone: nursery area for the postlarvae of estuarine associated fish species? Est. Coast. Shelf. Sci. 29: 533-547. https://doi.org/10.1016/0272-7714(89)90009-7 